\title{
Cultural Resources Assessment of Midland North Loop Midland County, Texas
}

Joe T. Denton

Follow this and additional works at: https://scholarworks.sfasu.edu/ita

Part of the American Material Culture Commons, Archaeological Anthropology Commons, Environmental Studies Commons, Other American Studies Commons, Other Arts and Humanities Commons, Other History of Art, Architecture, and Archaeology Commons, and the United States History Commons

Tell us how this article helped you.

This Article is brought to you for free and open access by the Center for Regional Heritage Research at SFA ScholarWorks. It has been accepted for inclusion in Index of Texas Archaeology: Open Access Gray Literature from the Lone Star State by an authorized editor of SFA ScholarWorks. For more information, please contact cdsscholarworks@sfasu.edu. 


\section{Cultural Resources Assessment of Midland North Loop Midland County, Texas}

\section{Licensing Statement}

This is a work produced for the Texas Department of Transportation (TxDOT) by the report producer. TxDOT and the report producer jointly own all rights, title, and interest in and to all intellectual property developed under TXDOT's contract with the report producer. The report may be cited and brief passages from this publication may be reproduced without permission provided that credit is given to both TxDOT and the report producer. Permission to reprint an entire chapter, section, figures or tables must be obtained in advance from either the Supervisor of the Archeological Studies Branch, Environmental Affairs Division, Texas Department of Transportation, 125 East 11th Street, Austin, Texas, 78701 or from the report producer. 


\title{
Cultural Resources Assessment of Midland North Loop
} Midland County, Texas

\author{
Joe T. Denton
}

Texas

State Department of Highways and Public Transportation Highway Design Division

October 1983 
ARCHAEOLOGICAL SITES 41MD19 AND 41MD23

Cultural resources assessment and archaeological testing was conducted on the proposed Midland North Loop by the State Department of Highways and Public Transportation (SDHPT) during the period October 4 through October 7, 1983, by a member of the SDHPT cultural resources staff and local SDHPT assistants. Additional collaboration was received from Dr. Michael Collins and other members of the Midland Archeological Society. The area within the proposed project is rural farm and ranchland with some urban development. The area is level to nearly level farmland with stable and active dunes. Drainage in the area consists primarily of playas. The project involves construction of a four-lane divided roadway with access roads. The area under investigation involves existing roadways and new location (Fig. 1). Two archaeological sites in the vicinity had been reported previously and were recommended for additional investigation (Fig. 1).

Testing of the two sites, 41MD19 and 41MD23, was conducted in accordance with Procedures for the Protection of Historic and Cultural Properties (36 CFR, Part 800), procedures prescribed and endorsed by the Federal Highway Administration. Testing was to determine the eligibility for inclusion to the National Register of Historic Places.

Testing objectives were to determine the location and significance of cultural deposits within the SDHPT right-of-way. Excavation consisted of hand-excavated test units, shovel tests, and machine-excavated trenches. Artifacts recovered were bagged and labeled as to provenience and were retained for analysis at the SDHPT cultural resources laboratory. Hand excavation consisted of controlled excavation of test units in $10 \mathrm{~cm}$ levels, and all soil was screened through 1/4 in. hardware cloth. Archaeological testing concentrated on Site 41MD23 although shovel tests were placed in the SDHPT right-of-way proximal to the location of Site 41MD19. 
This Page Redacted Per THC Policy 
On the basis of information from members of the Midland Archaeological Society, first-hand surface observations, as well as hand-excavated shovel tests, Site 41MD19 was determined to be well outside the SDHPT right-of-way. The site is located on a crest some 300 yards south of the present county road and the SDHPT right-of-way. Surface observation and shovel tests were made with negative results. Local information indicates that the site has a wide range of cultural manisfestation ranging from Archaic to Late Prehistoric materials. Several cultural concentrations have been noted by the local society members and landowners.

Site 41MD23, when first reported, was shown to be proximal to the SDHPT right-of-way, but further investigations indicated that cultural material and cultural deposits were contained within the right-of-way. Evidence of the site was found in the plowed field north of the county road and in the blow-out and plowed field areas within the right-of-way. Cultural evidence consisted of a few scattered flakes and occassional burned rocks Evidence located to the north outside the project area included flakes, burned rocks, and a modified flake.

Excavations at Site 41MD23 consisted of three controlled test units-one 1 by 2 meter unit and two 1 by 1 meter units, two shovel tests, profiles, and four machine-excavated trenches (Fig. 2). Test Unit 1 was located in an active dune area and was excavated to a depth of 1 meter. Test Unit 2 was excavated in a plowed field and was excavated to a depth of $30 \mathrm{~cm}$. Test Unit 3 was placed in the edge of a blow-out in an area of widely scattered burned rocks. No cultural evidence was recovered in any of the test units.

In order to test for the presence of buried deposits and possible cultural materials, four machine-cut trenches were excavated. The trenches indicated the presence of a stable dune formation below the active dunes. The stable dune formation, Sharvana fine sandy loam (Hyde 1973), was examined by Dr. Michael Collins of Midland, Texas, and was verified as the primary culture-bearing zone exposed in the plowed field and blowout areas. 


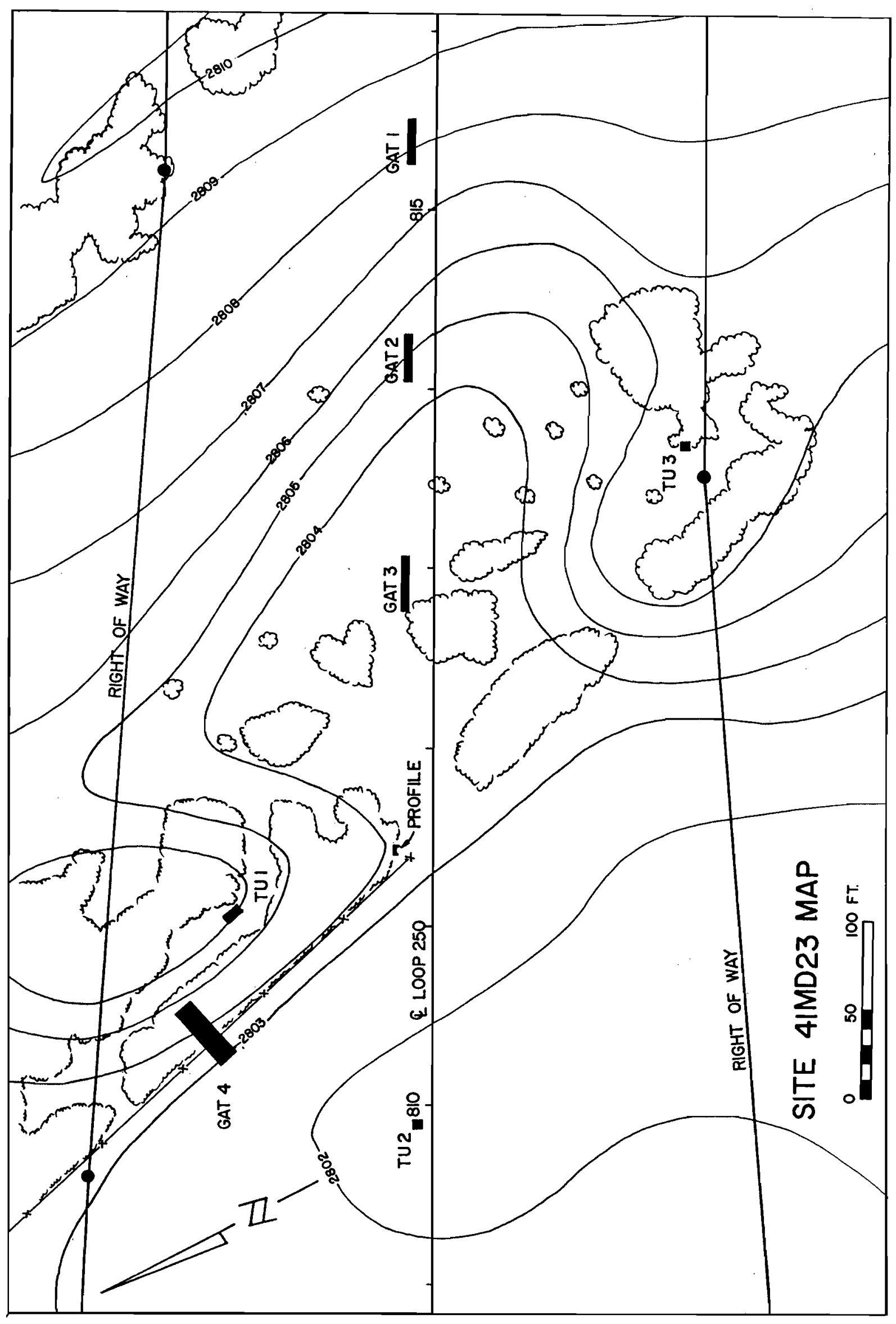


Gradall Trenches 1 through 4 indicated that the stable dune material increased in thickness from east to west toward a playa. No cultural material or features were noted in the Gradall trenches.

Profiles were made of a portion of Gradall Trench 4 (Fig. 3) and of the active dune. Soil samples from the Sharvana fine sandy loam which was considered to be the cultural zone were taken for radiocarbon dating because of the apparent high organic content. This date hopefully will aid future archaeological work in the region as similar or equivalent soils are known at other archaeological sites.

On the basis of testing and surface observations, Site 41MD23 is not recommended for further investigation due to the general paucity of cultural material and lack of features. It is believed that the portions of Site 41MD23 within the SDHPT right-of-way do not meet the criteria for inclusion within the National Register.

Site 41MD19 was determined to be outside the SDHPT project, and therefore no further work is recommended. 


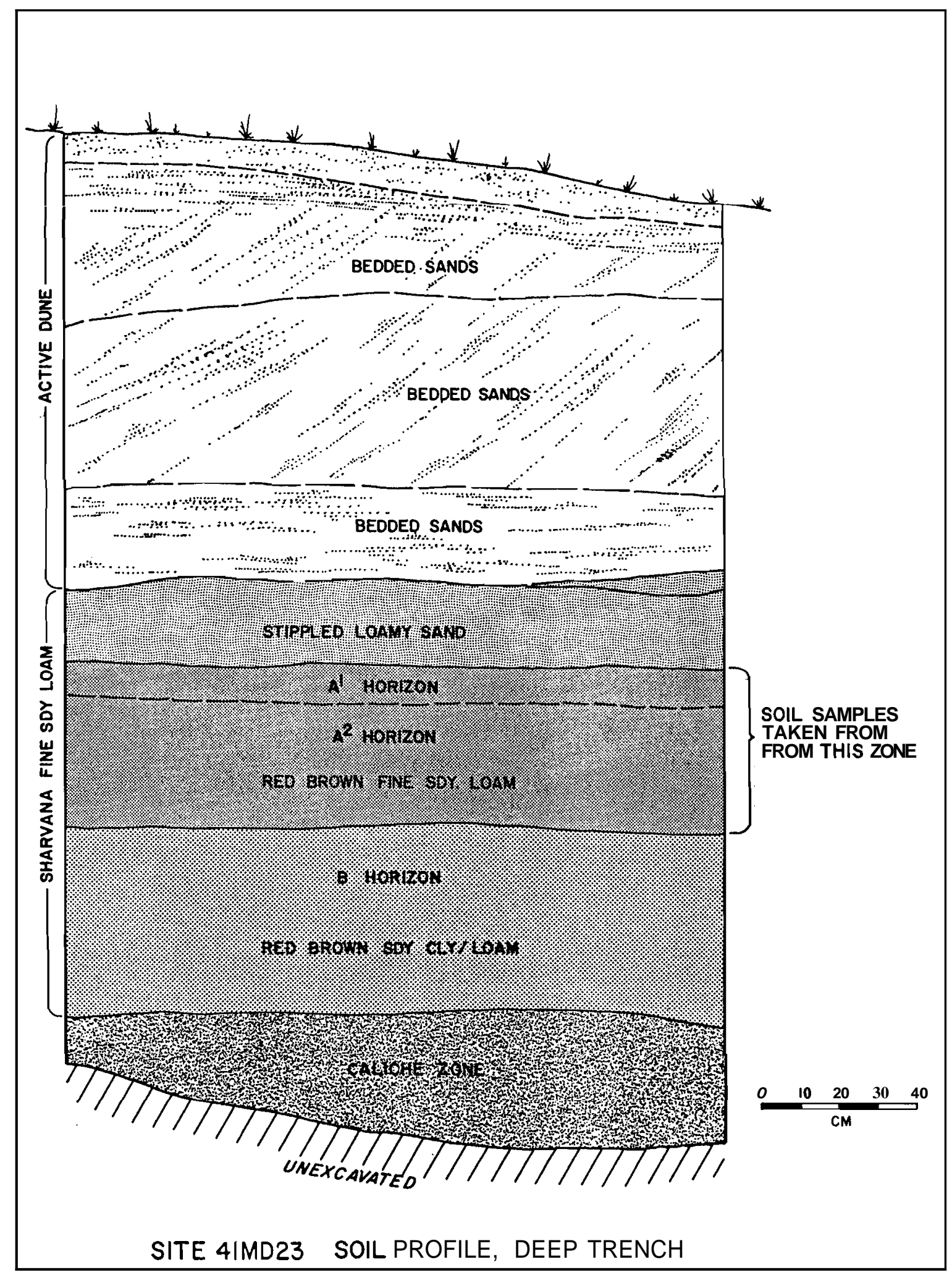

FIGURE 3. Soil profile. 
REFERENCES CITED

Hyde, Harold w.

1973 Soil Survey of Midland County. United States Department of Agriculture, Soil Conservation Service. U.S. Government Printing Office, Washington, D.C. 